\title{
USING LANDSAT-8 DATA TO EXPLORE THE CORRELATION BETWEEN URBAN HEAT ISLAND AND URBAN LAND USES
}

\author{
Rayan H. Alhawiti ${ }^{1}$, Diana Mitsova ${ }^{2}$ \\ ${ }^{1,2}$ School of Urban and Regional Planning, Florida Atlantic University, Boca Raton, Florida, USA.
}

\begin{abstract}
On a local scale, climate change can potentially exacerbate the urban heat island (UHI) effect characterized by an abrupt the rmal gradient between urbanized and nearby non-urbanized areas. While it is well-known that the presence of impervious surfaces and less vegetation influence urban microclimate, relatively little attention has been given to the spatial patterns of urban heat islands and how these patterns are affected by land use. In this study, we derive land surface temperature (LST) from Landsat 8 data over four time frames and analyze the relationship between urban thermal environments and urban land use. Landsat 8 Thermal Infrared Sensor (TIRS) and Operational Land Imager (OLI) band data are converted to top-of-atmosphere spectral radiance using radiance rescaling factors. At-satellite brightness temperature was retrieved and the land surface emissivity was calculated. In addition, Normalized Difference Vegetation Index and Normalized Difference Built-up Index were computed and their correlations with LST for each land use were examined. The results indicate that the highest maximum land surface temperature was observed in high density residential and commercial areas near city's downtown. Coastal areas and areas near water bodies are found to have lower land surface temperatures. The results from this study can inform planning and zoning practices aimed at reducing the urban heat island effect and creating a cooler and more comfortable thermal environment for city residents.
\end{abstract}

Keywords: Urban Heat Island, Land Surface Temperature, NDVI, NDBI, Land Use, Kruskal-Wallis Nonparametric Test.

\section{INTRODUCTION}

In its Fourth Assessment (AR4), the Intergovernmental Panel on Climate Change (IPCC) indicated that "observed warming has been, and transient greenhouse-induced warming is expected to be, greater over land than over the oceans" [1, ch3s3-2-2-2]. Various land uses possess thermal properties that can considerably impact the generation of extreme land surface temperatures [2]. A study conducted by Hamdi [3] in Brussels, Belgium, found a linear rise in the lowest and highest daily temperatures throughout the summer over the past fifty years, although the latter changes were not statistically significant. Built up areas are grouped in different use categories depending on ownership, function, and activity [4]. Urban Heat Islands (UHIs) develop as heat is emitted from a range of built-up surfaces, when favorable meteorological conditions (i.e., direction and velocity of wind, low water vapor content) are present [5]. An urban heat island effect is defined as the abrupt rise of the isothermic curve at the boundary of a highly urbanized area which modifies its thermal characteristics compared to those of the adjacent rural areas [5]. The United States Environmental Protection Agency (US EPA) differentiates between atmospheric UHIs and surface UHIs [2]. The atmospheric UHI is characterized by highest intensity during summer nights when air is stagnant while the surface UHI reaches its maximum heat release in the afternoon as sunlight is absorbed, then released back into the environment, by physical land structures.

Historically, the study of urban heat island formation has relied on time series data from air temperature measurements with high temporal resolution [6,7]. Recent studies have employed remote sensing data in various spatial resolutions to study land surface temperatures (LST) [8]. Starting in 2013, thermal data became available through bands 10 and 11 of the Landsat 8 Thermal Infrared Sensor (TIRS). Land surface temperature (LST) derived from the radiance emitted from a surface and quantified using the radiative transfer equation is known as radiometric temperature [9]. It is equivalent to thermodynamic temperature for isothermal surfaces [9].

Excessive temperatures can exert extreme heat stress on humans resulting in heat exhaustion, fainting, sunburn, heat rash, and even death [10-11]. In 1995, an unprecedented heat wave in Chicago resulted in over 500 deaths in five days $[12,13]$. The mega-heat wave of 2003 claimed nearly 70,000 lives in sixteen countries throughout Europe [14]. People living in areas affected by heat waves increasingly resort to utilizing air conditioners when temperatures are at their most extreme. Higher energy consumption for operating cooling systems has economic as well as environmental impacts, the most notable of which are the increase in associated costs and greenhouse gas emissions $[2,15]$. Understanding of how patterns of land development and land use spatial distribution affect the formation of urban heat islands can inform urban design and planning practices and lead to successful mitigation of temperature extremes [16].

Studies have shown that among the most important factors of anthropogenic heat are urban form, urban land use, and 
the thermal properties of buildings which, individually or in combination, can affect urban heat island formation $[2,16,17]$. Several factors play a role in urban heat island formation. Impervious surfaces block the processes of evaporation and evapotranspiration. In the natural environment, heat is transported away from soil and vegetation surfaces at a rate that depends on humidity and wind speed across the surface $[18,19,20]$. Dark, impermeable surfaces such as asphalt and concrete trap heat and effectively remove moisture from the air reducing its cooling properties. Presence of vegetation and trees can result in increased moisture content and shade which would allow urban environments to maintain lower temperatures $[2,19,20]$.

Existing patterns of urban development have produced a number of environmental impacts including loss of natural areas and vegetation $[21,22,23]$. While it is possible for a UHI to arise in smaller towns and cities, recent studies reveal correlation between the intensity of UHI and the extent of the developed area [2]. The urban heat island effect is often stronger in downtown areas [2,24]. Central business districts are dominated by high-rise buildings which can increase sunlight absorption and inhibit the outflow of heat $[6,7,25]$. Using mobile measurements in Debrecen, Hungary, Battyanet al. [26] established that an urban heat island exhibit a concentrically shaped pattern with a temperature gradient gradually increasing as one moves inwards. Higher temperatures of more than $2^{\circ} \mathrm{C}$ were registered at the center of the concentrically shaped area during the summer months. During colder months, the temperature difference reached more than $2.5^{\circ} \mathrm{C}$. The study also found strong correlation between thermal spatial patterns and selected land use variables [26].

Various research projects have sought to investigate UHI spatial patterns [24,26,27]. A study of land surface temperature of various land uses conducted in the City of Ho Chi Minh in North Vietnam [26] showed extreme temperatures in excess of $45^{\circ} \mathrm{C}$ recorded on industrial land uses. Other land use types such as commercial and high density residential were also associated with high land surface temperatures in the range of $36^{\circ} \mathrm{C}$ to $40^{\circ} \mathrm{C}$.A study conducted in Beijing, China, established a positive correlation between impermeable surfaces and land surface temperatures [27]. Stone and Norman [28] found that modifications in the sub-division design and zoning regulations in Atlanta, Georgia, can reduce UHI intensity by up to $40 \%$. An analysis of the relationship between land use and UHI intensity in Singapore resulted in an ordered scale from low to high intensity by land use type [24]. Parks ranked lower on the scale while residential areas, airports, and commercial and industrial land uses exhibited progressively higher UHI intensity levels [24]. A study of land surface temperature in Nanjing, China, found that higher LST is negatively correlated with the Normalized Difference Vegetation Index (NDVI) $(r=-0.59)$ [29]. The study results also revealed greater cooling effect of larger vegetated areas over smaller ones [29]. Vlassovaet al.[30] used Radiative Transfer to extract LST from Landsat-5 TM images, obtained from 2009 to 2011. The study found a seasonal bias in Landsat-MODIS LST variations due to large differences in surface emissivity and thermal differences between various components of the land cover. Kim et al.[31] suggested a method for quantifying and classifying deviations between ETM+ and TM. The correlations for change detection in urban land cover were analyzed for four time points of data over a period of 15 years in Korea. The study found high correlations between the lowest vegetation index and the highest LST which was used as a proof of concept for land cover change monitoring and detection [31].

The main objective of this research is to examine the correlation between land surface temperatures (LST) and urban land uses during four time frames between March $23^{\text {rd }}$ and November $2^{\text {nd }}, 2014$. Specific objectives include (1) convert Landsat 8 Thermal Infrared Sensor (TIRS) and Operational Land Imager (OLI) band data to top-ofatmosphere spectral radiance using radiance rescaling factors; (2) retrieve at-satellite brightness temperature, calculate land surface emissivity, and derive land surface temperature; (3) derive Normalized Difference Vegetation Index and Normalized Difference Built-up Index; and (4) explore the correlation between land surface temperatures, NDVI, NDBI and land use. The rest of this paper is organized as follows. After a brief overview of studies that examine the characteristics of urban heat islands (covered in the introduction), we discuss data, data sources, and data processing. The findings from the analysis are presented next, followed by conclusions and recommendations for future research.

\section{STUDY REGION AND DATA PROCESSING}

\subsection{Study Area}

The City of Fort Lauderdale, located in Broward County, on Florida's southeast coast, was selected as the study area for this research (Figure 1). The city is located between the $80^{\circ} 06^{\prime} 08.7^{\prime \prime} \mathrm{W}$ to $80^{\circ} 12^{\prime} 02.5^{\prime \prime} \mathrm{W}$ longitude and $26^{\circ} 12^{\prime} 43.0^{\prime \prime} \mathrm{N}$ to $26^{\circ} 12^{\prime} 32.6^{\prime \prime} \mathrm{N}$ latitudes. Fort Lauderdale has an area of $99.9 \mathrm{~km}^{2}$. In 2013, the city had a population of 172,389 and ranked eighth among Florida's largest cities. The city has a subtropical climate, and temperatures between seasons do not vary significantly. The average temperatures range from 22-24 ${ }^{\circ} \mathrm{C}\left(71-76^{\circ} \mathrm{F}\right)$ to $30-32{ }^{\circ} \mathrm{C}\left(86-90{ }^{\circ} \mathrm{F}\right)$ [32].

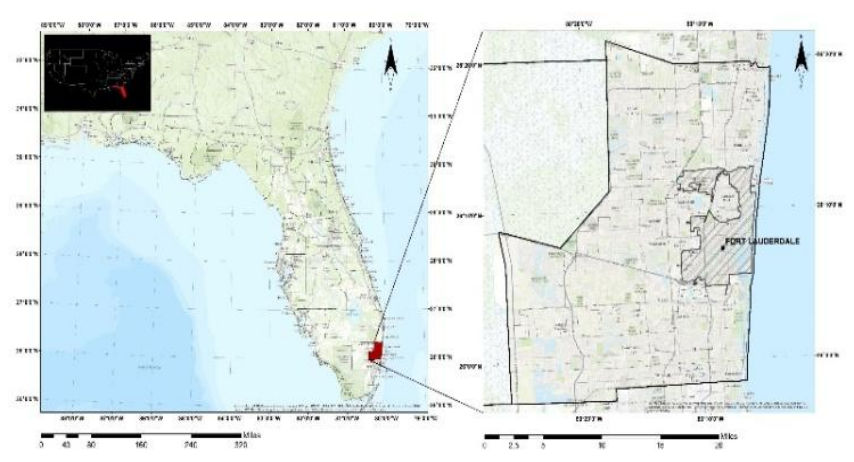

Fig -1: Map of Broward County (right) showing the location of Fort Lauderdale. 


\subsection{Data Source}

Four near cloud-free Landsat-8 (OLI and TIR) images (Row:015/Path:042) were collected from the U.S. Geological Survey's Earth Resources Observation and Science (EROS). The images were acquired on 23 March 2014, 23 April 2014, 17 October 2014, and 02 November 2014, as shown in Table 1. The data has already georeferenced to the UTM coordinate system (Zone 17N) using the WGS 1984 spheroid. Land-Use/Land Cover (LULC) data for this study was obtained from The South Florida Water Management District (SFWMD) (Figure 2). Since the data has several LULC levels, data reclassification has to be carried out to consolidate various land uses. The land use data is reclassified based on the Florida Land Use and Cover Classification System (FLUCCS).

Table 1: Characteristics of the Landsat 8 images.

\begin{tabular}{|cccccc|}
\hline $\begin{array}{c}\text { Acquisition } \\
\text { Date }\end{array}$ & Acquisition Time & $\begin{array}{c}\text { Scene Center } \\
\text { (Lat/Lon) }\end{array}$ & $\begin{array}{c}\text { Cloud Cover } \\
(\%)\end{array}$ & $\begin{array}{c}\text { Sun Elevation } \\
\text { (Degree) }\end{array}$ & Sun Azimuth (Degree) \\
\hline 23 March 2014 & $15: 50: 23$ & $\begin{array}{l}25^{\circ} 59^{\prime} 15.3492^{\prime \prime} \mathrm{N} / \\
80^{\circ} 25^{\prime} 13.8432^{\prime \prime} \mathrm{W}\end{array}$ & 1.52 & 55.88 & 132.43 \\
24 April 2014 & $15: 49: 53$ & $\begin{array}{c}25^{\circ} 59^{\prime} 15.3960^{\prime \prime} \mathrm{N} / \\
80^{\circ} 25^{\prime} 24.6432^{\prime \prime} \mathrm{W}\end{array}$ & 5.34 & 65.26 & 117.06 \\
17 October 2014 & $15: 50: 16$ & $\begin{array}{c}25^{\circ} 59^{\prime} 20.0724^{\prime \prime} \mathrm{N} / \\
80^{\circ} 24^{\prime} 36.0504^{\prime \prime} \mathrm{W}\end{array}$ & 0.37 & 50.14 & 149.62 \\
02 November 2014 & $15: 50: 13$ & $\begin{array}{l}25^{\circ} 59^{\prime} 19.9392^{\prime \prime} \mathrm{N} / \\
80^{\circ} 24^{\prime} 3.6864^{\prime \prime} \mathrm{W}\end{array}$ & 2.57 & 45.40 & 153.75 \\
\hline
\end{tabular}

In examining the relationship between land surface temperature and land use, previous studies have worked with a relatively small number of land use categories, most commonly five [33]. We consolidated over fifty different types of land categories into ten urban land use classes which include: three residential use categories based on urban density, upland hardwood forests, transportation and utilities, services and commercial areas, industrial areas, parks and cemeteries, water bodies, and coastal vegetation (Table 2).

Table 2: Classification system of urban land uses

\begin{tabular}{|c|c|}
\hline \multicolumn{2}{|c|}{ Land use Categories } \\
\hline Level IV & Level III \\
\hline $\begin{array}{l}\text { Low } \\
\text { Density } \\
\text { Residential }\end{array}$ & $\begin{array}{l}\text { Fixed single family units <less than } \\
\text { two dwelling units per acre> } \\
\text { Fixed single family units <two-five } \\
\text { dwelling units per acre }> \\
\text { Multiple dwelling units, low rise } \\
<\text { two stories or less }>\end{array}$ \\
\hline $\begin{array}{l}\text { Medium } \\
\text { Density } \\
\text { Residential }\end{array}$ & $\begin{array}{l}\text { Fixed single family units <six or } \\
\text { more dwelling units per acre> } \\
\text { Mobile home units <six or more } \\
\text { dwelling units per acre> } \\
\text { Residential, medium density under } \\
\text { construction <two-five dwelling units } \\
\text { per acre> }\end{array}$ \\
\hline $\begin{array}{l}\text { High } \\
\text { Density } \\
\text { Residential }\end{array}$ & $\begin{array}{l}\text { Multiple dwelling units, high rise } \\
\text { <three stories or more> } \\
\text { Residential, high density under } \\
\text { construction <six or more dwelling } \\
\text { units per acre> }\end{array}$ \\
\hline $\begin{array}{l}\text { Commercial } \\
\text { and } \\
\text { Services }\end{array}$ & $\begin{array}{l}\text { Commercial and services } \\
\text { Commercial and services under } \\
\text { construction } \\
\text { Retail sales and services } \\
\text { Stadiums <those facilities not } \\
\text { associated with high schools, }\end{array}$ \\
\hline
\end{tabular}

\begin{tabular}{|c|c|}
\hline & $\begin{array}{l}\text { colleges or universities> } \\
\text { Wholesale sales and services } \\
\text { <excluding warehouses associated } \\
\text { with industrial use> }\end{array}$ \\
\hline Industrial & $\begin{array}{l}\text { Electric power facilities } \\
\text { Oil and gas storage } \\
\text { Other light industrial } \\
\text { Port facilities } \\
\text { Sewage treatment } \\
\text { Water supply plants }\end{array}$ \\
\hline $\begin{array}{l}\text { Parks } \\
\text { and } \\
\text { Cemeteries }\end{array}$ & $\begin{array}{l}\text { Cemeteries } \\
\text { Parks and zoos } \\
\text { Swimming beach }\end{array}$ \\
\hline $\begin{array}{l}\text { Lakes } \\
\text { and } \\
\text { Rivers }\end{array}$ & $\begin{array}{l}\text { Channelized river, stream, waterway } \\
\text { Reservoirs } \\
\text { Lakes }\end{array}$ \\
\hline $\begin{array}{l}\text { Coastal } \\
\text { Wetland } \\
\text { Vegetation }\end{array}$ & $\begin{array}{l}\text { Emergent aquatic vegetation } \\
\text { Freshwater marshes } \\
\text { Mangrove swamps } \\
\text { Mixed wetland hardwoods }\end{array}$ \\
\hline $\begin{array}{l}\text { Upland } \\
\text { Hardwood } \\
\text { Forests }\end{array}$ & $\begin{array}{l}\text { Australian pines } \\
\text { Brazilian pepper } \\
\text { Sand pine } \\
\text { Upland hardwood forests }\end{array}$ \\
\hline $\begin{array}{l}\text { Transportation } \\
\text { and } \\
\text { Utilities }\end{array}$ & $\begin{array}{l}\text { Airports } \\
\text { Communications } \\
\text { Educational facilities } \\
\text { Golf courses } \\
\text { Institutional } \\
\text { Marinas and fish camps } \\
\text { Open land } \\
\text { Railroads } \\
\text { Recreational } \\
\text { Roads and highways } \\
\text { Transportation }\end{array}$ \\
\hline
\end{tabular}




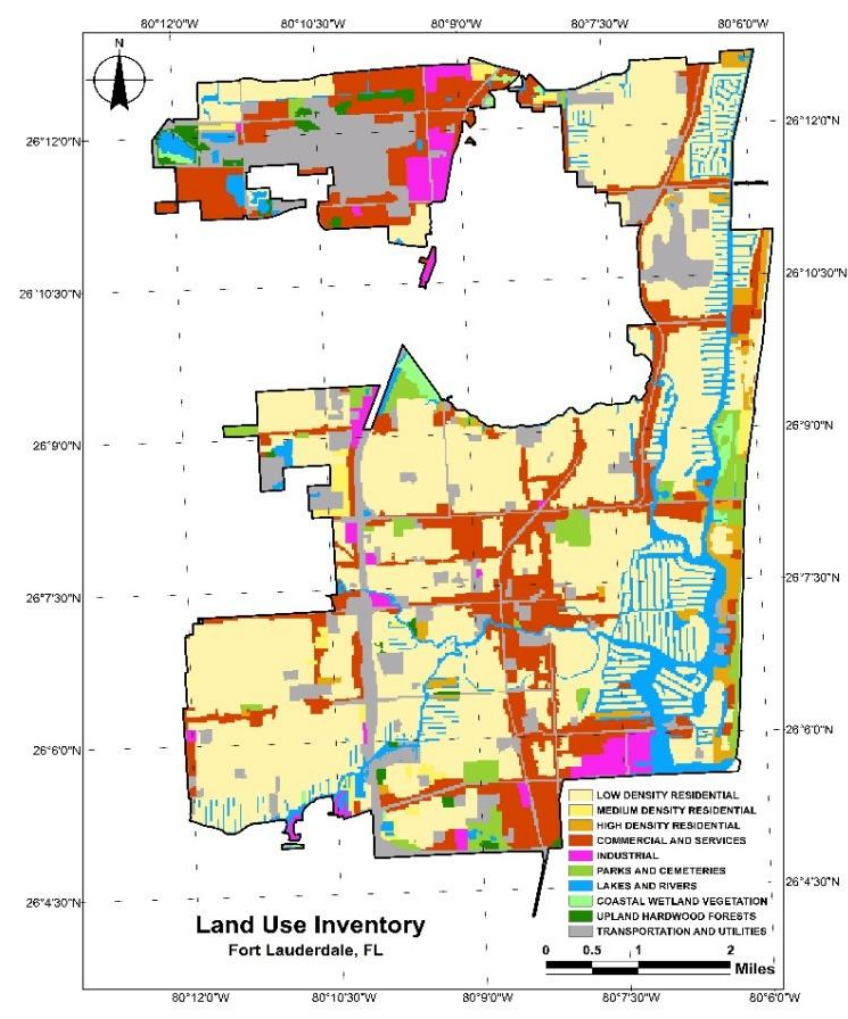

Fig -2:Land-Use/Land Cover (LULC) data.

\section{RETRIEVING LAND SURFACE TEMPERATURE (LST)}

LST is a key component of Soil-Vegetation-Atmosphere transfer modeling in terrestrial ecosystems [30]. Percent surface imperviousness (SI) and LST have been used to describe the characteristics of the urban heat island effect [30,31,34]. Kumar et al. [34] argued that an in-depth understanding of LST distributions and spatial variations can assist in developing models of LST dynamics and finding environmentally sustainable solutions.

A flowchart of the research process is described in Figure 3. The analysis steps include LST estimation using thermal infrared sensor band 10 and operational land imager band 26 coefficients are obtained from the metadata file. Imageprocessing algorithms and data analysis were performedusing Esri ${ }^{\circledR} \operatorname{ArcMap}^{\mathrm{TM}}$ v. 10.3 geoprocessing packages and IBM SPSS ${ }$ software.

\subsection{Retrieving Top-Of-Atmosphere}

(TOA)

\section{Radiance and Reflectance}

The United States Geological Survey (USGS) released the Landsat 8 data with a description of a step-by-step process of deriving LST [35]. The Landsat 8 TIRS and OLI band data

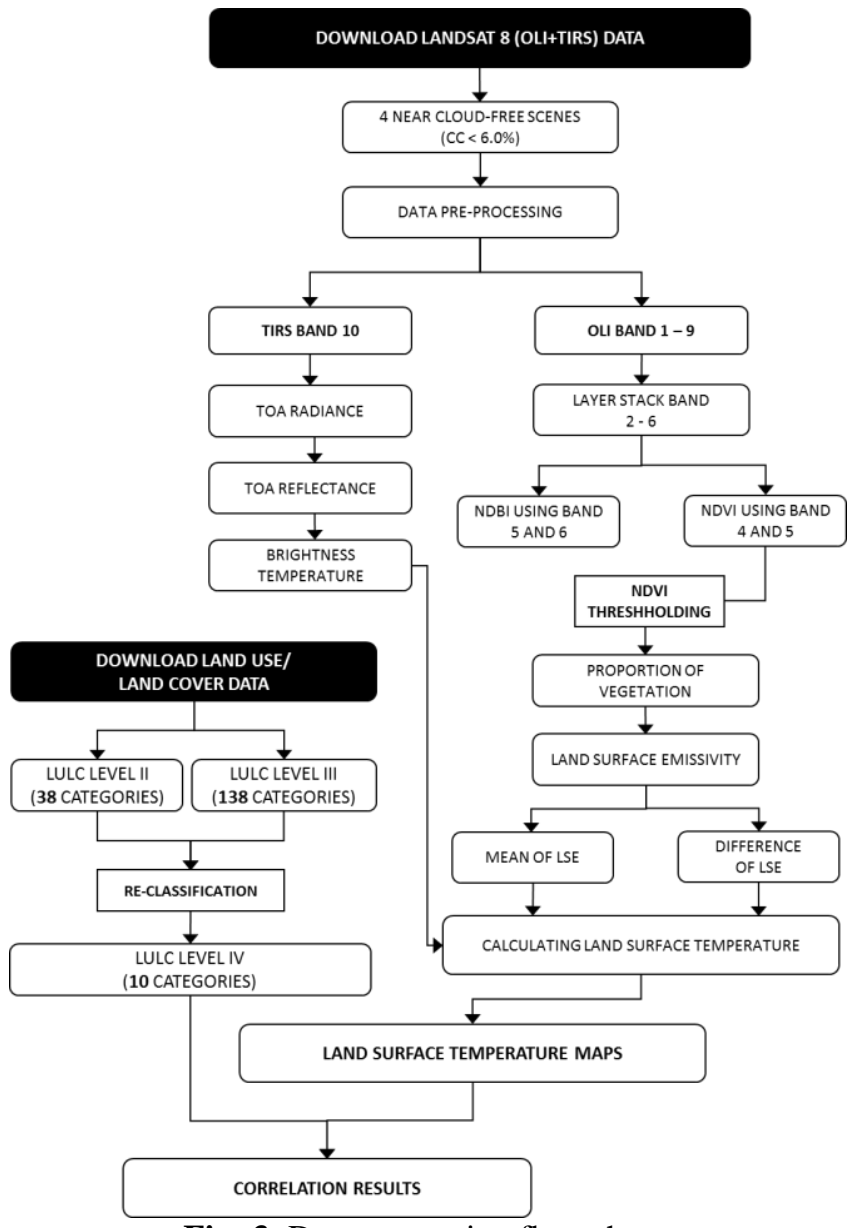

Fig -3: Data processing flow chart.

are converted to TOA spectral radiance using the radiance rescaling factors specific to each band provided in the metadata file:

$L_{\lambda}=M_{\mathrm{L}} Q_{c a l}+A_{\mathrm{L}}$

where $L_{\lambda}$ is the TOA spectral radiance (Watts $/\left(\mathrm{m}^{2} \cdot \mathrm{sr} \cdot \mu \mathrm{m}\right), Q_{c a l}$ is the pixel value $(\mathrm{DN})$, and $M_{\mathrm{L}}$ and $A_{\mathrm{L}}$ are rescaling coefficients [35]. Similar procedure is followed for the computation of TOA planetary reflectance using the Operational Land Imager (OLI) band 2-6 data which also contains a correction for the sun angle [35].

\subsection{Land Surface Emissivity Calculation}

Temperature data presented above refer to a black body, hence, it is essential to correct for spectral emissivity $(\varepsilon)$ to account for changes in land cover. As a function of wavelength [36], spectral emissivity can be influenced by various properties of a surface: composition; chemical and physical properties; and surface roughness [37]. Emissivity of vegetated surfaces is affected by plant species, density, and plant growth [37]. The emissivity of the bare soil and the total vegetation-covered area take empirical values of 0.973 and 0.986 , respectively [39]. The vegetation mixed coverage area and bare soil areas is calculated by Equation (2) [40].

$\varepsilon=\varepsilon_{v} P_{v} R_{v}+\varepsilon_{s}\left[1-P_{v}\right] R_{s}+d_{\varepsilon}$ 
$R_{v}=\left(0.92762+0.07033 P_{v}\right)$

$R_{s}=\left(0.99782+0.05362 P_{v}\right)$

where, $\boldsymbol{\varepsilon}_{\boldsymbol{v}}$ is the vegetation emissivity (0.986), $\boldsymbol{\varepsilon}_{\boldsymbol{s}}$ is the bare soil emissivity (0.973), $\boldsymbol{P}_{\boldsymbol{v}}$ is the vegetation proportion in a pixel, and $\boldsymbol{d}_{\boldsymbol{\varepsilon}}$ is the topography factor. Due to its flatness, the terrain effect of the study area was considered negligible.

\subsection{NDVI and NDBI Calculation}

The Normalized Difference Vegetation Index (NDVI) is the most commonly used satellite-based measure of vegetatedregions[41]. The NDVI is calculated using Equation (5) [40]. Land surface emissivity was calculated using the NDVI threshold method [38] suggested byBeck et al. [42]. The assumption is that bare has a NDVI < 0.2 [42]. The land surface is considered to be completely covered by vegetation if NDVI $>0.5$ [42]. When the NDVI values are between 0.1 and $0.5(0.1 \leq \mathrm{NDVI} \leq 0.5)$, the land surface is considered to be covered by vegetation and bare soil mixing.

$N D V I=\frac{R_{N I R}-R_{R E D}}{R_{N I R}+R_{R E D}}$

where $R_{N I R}$ and $R_{R E D}$ are reflectances in the near-infrared band $(0.85-0.88 \mu \mathrm{m})$ and the red band $(0.64-0.67 \mu \mathrm{m})$, respectively.

The Normalized Difference Built-up Index (NDBI) is a useful measure of the intensity of imperviousness using satellite data [43]. This index was originally developed for use with bands 4-5 from TM imagery. Nonetheless, the NDBI can work with Landsat-8 data or any multispectral sensor [44]. It highlights the urban areas distribution where there is typically a higher reflectance in the short-wave infrared band compared to the near-infrared band. The accuracy of extracting built-up areas by usingthis index was nearly 93\% [45,46]. The NDBI is calculated using the following Equation (6) [45]:

$N D B I=\frac{S W I R-N I R}{S W I R+N I R}$

whereSWIR is the short-wave infrared band in the range of $1.57-1.65 \mu \mathrm{m}$, and NIR is the near-infrared band in the range of $0.85-0.88 \mu m$, respectively. Figures 4 and 5 display the results of the NDVI and NDBI calculation.

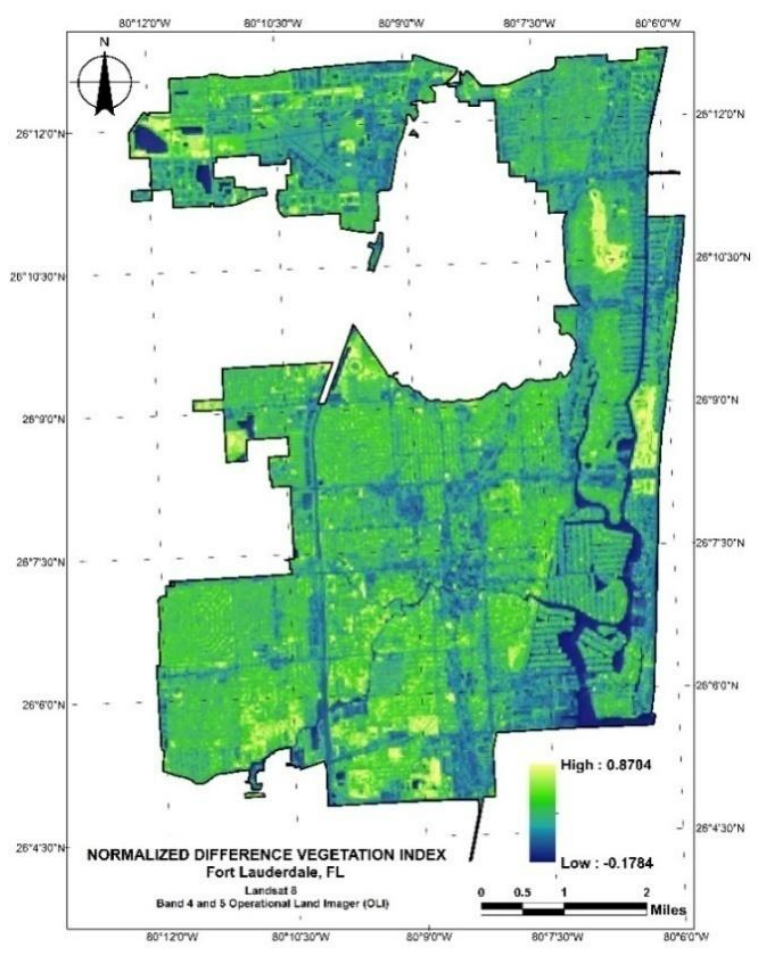

Fig -4: NDVI map of the study region.

\subsection{Retrieving LST}

Following [35], the LST is calculated using Equation (7).

$T_{S}=\frac{T_{\text {rad }}}{1+\left(\lambda \cdot T_{\text {rad }} / \rho\right) I n_{\varepsilon}}-273.15$

where $T_{S}$ is the LST and its unit is Degrees Celsius $\left({ }^{\circ} \mathrm{C}\right)$; $T_{\text {rad }}$ is the brightness temperature (BT) in Kelvin (K); $\lambda$ is the center wavelength for band $10(10.9 \mu \mathrm{m}) ; \rho=h \cdot c / \sigma$, where $h$ is the Planck constant $\left(6.626 \times 10^{-34} \mathrm{~J} \cdot s\right), c$ is the velocity of light $\left(2.998 \times 10^{8} \mathrm{~m} / \mathrm{s}\right), \sigma$ is the Boltzmann constant $\left(1.38 \times 10^{-23} \mathrm{~J} / K\right) ; \varepsilon$ is the surface emissivity [35].

\section{RESULTS}

We derived land surface temperature (LST), NDVI and NDBI for the city of Fort Lauderdale, Florida, using Landsat 8 data captured on March $23^{\text {rd }}$, April $24^{\text {th }}$, October $17^{\text {th }}$, and November $2^{\text {nd }}, 2014$. Figure 6 displays the spatial patterns of land surface temperature across the city on these four days. The map shows that the surface temperature on March 23rd, 2014 ranges from $20.90^{\circ} \mathrm{C}$ to $34.59^{\circ} \mathrm{C}$. The highest maximum land surface temperature was observed in high density residential and commercial areas near the city's downtown. In contrast, vegetated areas and areas near water bodies exhibit lower radiometric temperatures. Water bodies are associated with the lowest radiometric temperatures, with average values of $16.26^{\circ} \mathrm{C}$. These areas are shown in dark blue on the maps. The data has a pixel size of $30 \mathrm{~m}$ by $30 \mathrm{~m}$. 


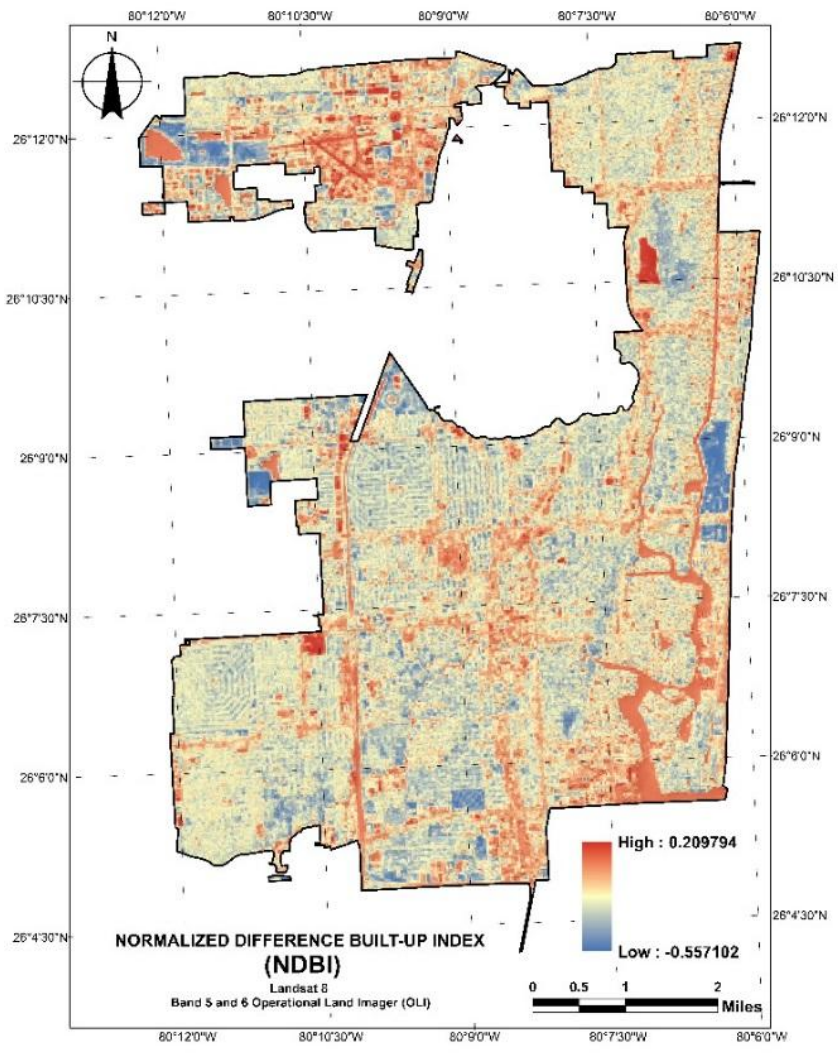

Fig -5: NDBI map of the study region.

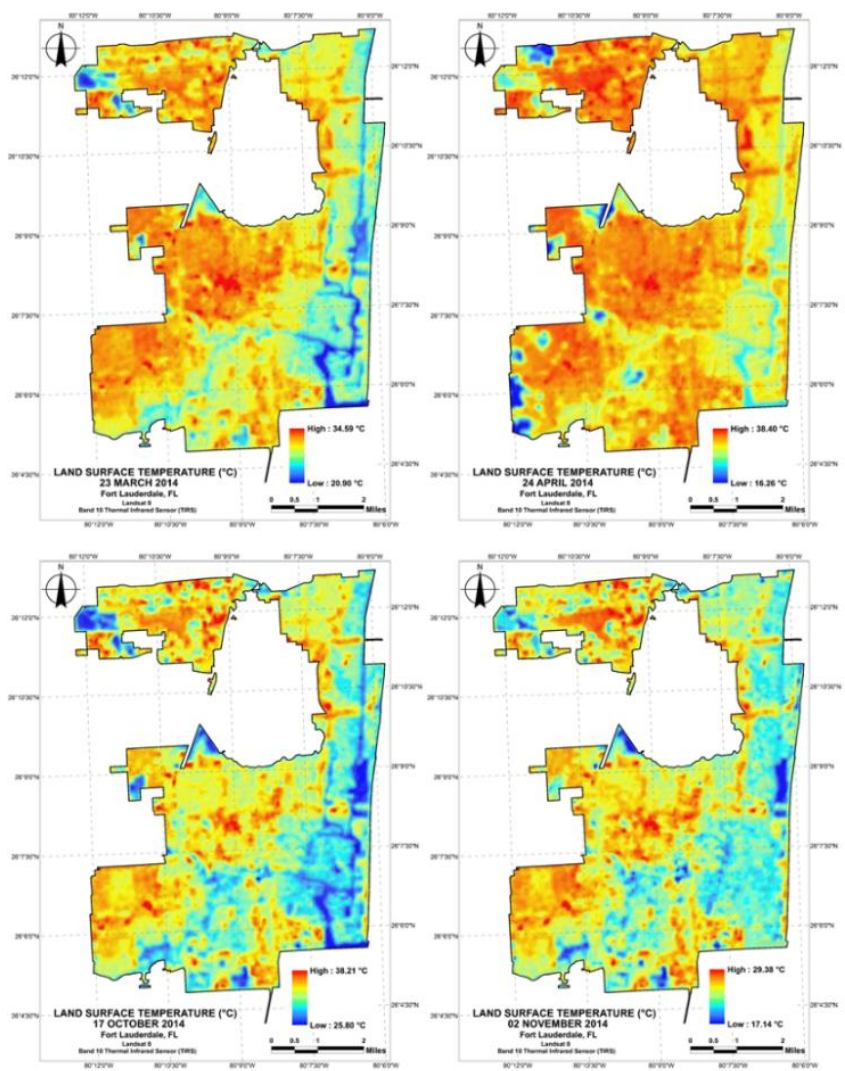

Fig- 6: LST distributions maps of the study area.

Table 3: Results of minimum, maximum, and standard deviation values for each land use types.

\begin{tabular}{|c|c|c|c|c|c|c|c|c|c|c|c|c|c|c|c|c|}
\hline & \multicolumn{16}{|c|}{ Land Surface Temperature in Degrees Celsius } \\
\hline & \multicolumn{4}{|c|}{23 March 2014} & \multicolumn{4}{|c|}{24 April 2014} & \multicolumn{4}{|c|}{17 October 2014} & \multicolumn{4}{|c|}{02 November 2014} \\
\hline & MIN & MAX & MEAN & STD & MIN & MAX & MEAN & STD & MIN & MAX & MEAN & STD & MIN & MAX & MEAN & STD \\
\hline Low Density Residential & 24.0 & 31.8 & 29.1 & 1.61 & 17.9 & 35.5 & 31.7 & 2.55 & 27.6 & 35.0 & 31.6 & 1.47 & 20.3 & 26.9 & 23.9 & 1.20 \\
\hline Medium Density Residential & 26.0 & 30.5 & 28.4 & 1.93 & 29.3 & 34.1 & 31.8 & 2.08 & 29.2 & 33.6 & 31.2 & 1.62 & 21.5 & 26.0 & 23.6 & 1.63 \\
\hline High Density Residential & 26.4 & 28.7 & 27.5 & 0.93 & 29.5 & 31.7 & 30.7 & 0.81 & 29.5 & 31.5 & 30.4 & 0.64 & 22.0 & 24.4 & 23.0 & 0.89 \\
\hline Commercial \& Services & 25.7 & 33.2 & 30.1 & 1.51 & 16.8 & 38.0 & 33.3 & 2.82 & 28.2 & 37.0 & 33.1 & 1.61 & 20.7 & 28.8 & 25.1 & 1.43 \\
\hline Industrial & 25.8 & 31.2 & 29.8 & 1.60 & 16.8 & 35.0 & 29.9 & 6.88 & 27.2 & 35.2 & 32.5 & 2.19 & 19.2 & 26.1 & 24.2 & 1.99 \\
\hline Parks \& Cemeteries & 25.1 & 31.4 & 27.7 & 2.32 & 27.8 & 34.4 & 30.5 & 2.35 & 28.0 & 33.8 & 30.3 & 2.03 & 21.2 & 26.4 & 23.2 & 1.81 \\
\hline Lakes \& Rivers & 22.3 & 29.0 & 25.7 & 1.93 & 25.0 & 32.2 & 28.2 & 2.03 & 26.7 & 32.0 & 29.0 & 1.36 & 21.3 & 24.2 & 22.9 & 0.64 \\
\hline Coastal Wetland Vegetation & 22.0 & 26.3 & 26.1 & 0.24 & 27.6 & 29.5 & 28.6 & 1.37 & 26.8 & 29.0 & 27.9 & 1.56 & 19.5 & 21.6 & 20.6 & 1.45 \\
\hline Upland Hardwood Forests & 25.3 & 27.3 & 26.3 & 0.82 & 28.1 & 31.4 & 29.5 & 1.28 & 28.0 & 29.1 & 28.5 & 0.40 & 21.4 & 22.8 & 22.1 & 0.49 \\
\hline Transportation \& Utilities & 26.8 & 31.9 & 29.7 & 1.25 & 21.7 & 37.2 & 32.5 & 2.77 & 27.8 & 35.0 & 32.2 & 1.58 & 22.2 & 27.2 & 24.5 & 1.16 \\
\hline
\end{tabular}

Table 3 presents minimum, maximum, and mean land surface temperature values in degrees Celsius $\left({ }^{\circ} \mathrm{C}\right)$ for the ten land use categories over four time frames. The results indicate that the "commercial and services" land use category is associated with the highest minimum, maximum and mean LST during all four periods. The highest observed value corresponds is $38.05^{\circ} \mathrm{C}$ recorded on April $24^{\text {th }}$. Land areas associated with transportation and utilities follow closely the trend exhibited by commercial land use. The maximum radiometric temperature for this land use category was $37.2^{\circ} \mathrm{C}$ measured on April 24. Industrial land use is associated with the third highest LST among the ten land use classes. LSTs associated with industrial land use also exhibit the highest standard deviation of 6.33. The lowest LST is associated with coastal wetland vegetation, followed by upland hardwood forests, and rivers and lakes. This result indicates that although industrial land use is associated with some of the highest LST measurements, overall effect on the urban heat island formation would be relatively low because the percent area associated with this category is low(Figure $7)$.

The highest percentage of land in the temperature range between $23.64^{\circ} \mathrm{C}$ and $24.90^{\circ} \mathrm{C}$ is again low density residential, which accounts for $54.4 \%$, followed by transportation and utilities which accounts for $21.9 \%$. In the "hottest" category (with temperatures of more than $24.90^{\circ} \mathrm{C}$ )commercial and services land use category accounts for $39.5 \%$ of the land in this category. Another land use category strongly linked to higher LST values is 
again low density residential which also account for $39.5 \%$. Next in this category is transportation and utilities, which accounts for $14.9 \%$. Analysis of higher temperature ranges confirms these results. Overall, in the temperature range between 30.42 and $32.80^{\circ} \mathrm{C}$, the highest land use is again low density residential, which accounts for $64.9 \%$, followed by transportation and utilities which account for $12.3 \%$. Finally, in the range of LST greater than $32.80{ }^{\circ} \mathrm{C}$, the highest percentage area is associated with high density residential which accounts for $44.1 \%$, followed by commercial land use which accounts for $31.6 \%$. An important observation here is that low density residential areas are associated with various microclimate regimes. These results suggest that factors, other than land use, such as vegetative cover may also play a role in the urban heat island formation.

Land Use

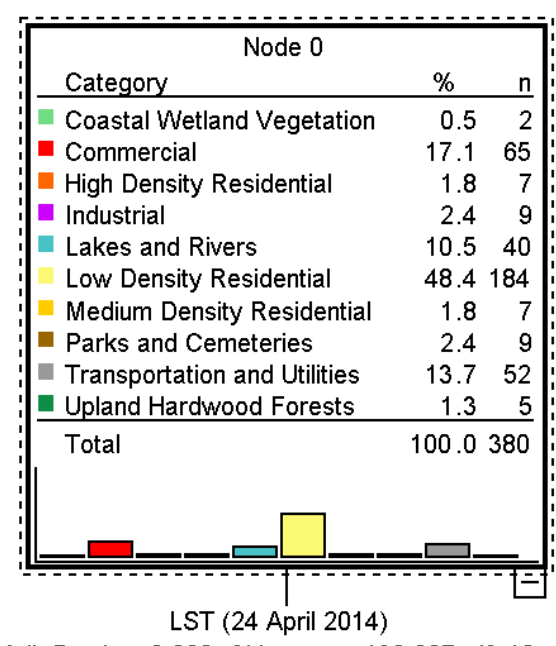

Adj. P-value $=0.000$, Chi-square $=138.807, \mathrm{df}=18$

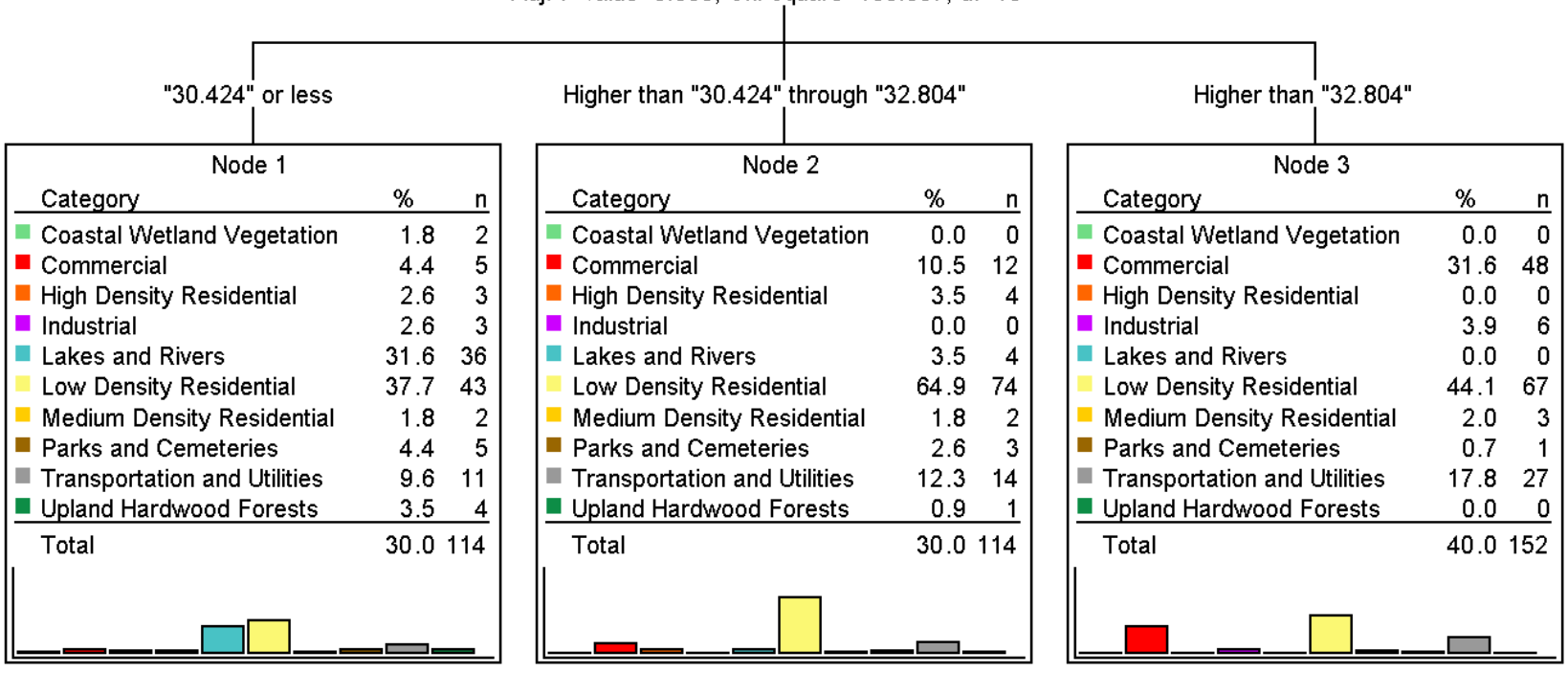

Fig -7: Tree-based model that classifies land use classes into three groups based on LST on April 24, 2014.

\subsection{Correlation Analysis}

The results from the previous section suggest a difference between the heat-trapping efficiency of various land uses. We used the Kruskal-Wallis non-parametric $\mathrm{H}$ test to determine if those differences are statistically significant. The test was corrected for tied ranks. Table 4 summarizes the results of the statistical analysis. The Kruskal Wallis $\mathrm{H}$ test was conducted for LST, NDVI, NDBI and all land use categories. The results indicate that there is a statistically significant difference between the thermal profile of various land use categorieswith regard toLST, vegetation coverage with regard to NDVI, and built-up profile with regard to
NDBI. For example, the value of the test using the March 23rd data was $\chi^{2}(9)=122.298$, $\mathrm{p}$-value $=0.000$. For April 24 th and October $17^{\text {th }}$ the value of the test was $\chi^{2}(9)=$ 111.626 , p-value $=0.000$, and $\chi^{2}(9)=134.152$, p-value $=$ 0.000 , respectively. Lastly, the November 2 nd data resulted in a test score of $\chi^{2}(9)=103.734, \mathrm{p}$-value $=0.000$. All tests are statistically significant. The results also indicate a positive correlation between LST and NDBI. The correlation analysis also reveals a fairly strong negative relationship between NDBI and NDVI and LST and NDVI (Figure 8). 
Table 4:Results of correlation coefficientsbetween LST, NDVI and NDBI

\begin{tabular}{|llccc|}
\hline & & Chi-Square & df & Asymp. Sig. \\
\hline \multirow{5}{*}{ LST } & 23 March 2014 & 122.298 & 9 & $4.520 \mathrm{E}-22$ \\
& 24 April 2014 & 111.626 & 9 & $6.858 \mathrm{E}-20$ \\
& 17 October 2014 & 134.152 & 9 & $1.658 \mathrm{E}-24$ \\
& 02 November 2014 & 103.734 & 9 & $2.759 \mathrm{E}-18$ \\
\cline { 2 - 5 } NDVI & 23 March 2014 & 123.275 & 9 & $2.850 \mathrm{E}-22$ \\
& 24 April 2014 & 120.573 & 9 & $1.020 \mathrm{E}-21$ \\
& 17 October 2014 & 119.875 & 9 & $1.418 \mathrm{E}-21$ \\
& 02 November 2014 & 122.976 & 9 & $3.283 \mathrm{E}-22$ \\
\cline { 2 - 5 } NDBI & 23 March 2014 & 105.560 & 9 & $1.175 \mathrm{E}-18$ \\
& 24 April 2014 & 107.207 & 9 & $5.441 \mathrm{E}-19$ \\
& 17 October 2014 & 105.441 & 9 & $1.242 \mathrm{E}-18$ \\
& 02 November 2014 & 104.662 & 9 & $1.788 \mathrm{E}-18$ \\
\hline
\end{tabular}

Table 5:Results of maximum, minimum, median, and standard deviation for the study area from the three different map types on four different dates.

\begin{tabular}{|llcccc|}
\hline & & Median & STD & Min. & Max. \\
\hline \multirow{4}{*}{ LST } & 23 March 2014 & 29.22 & 2.04 & 22.37 & 33.21 \\
& 24 April 2014 & 32.23 & 3.04 & 16.82 & 38.04 \\
& 17 October 2014 & 31.72 & 1.91 & 26.73 & 37.03 \\
& 02 November 2014 & 23.98 & 1.42 & 19.27 & 28.79 \\
\cline { 2 - 6 } NDVI & 23 March 2014 & 0.20 & 0.10 & -0.07 & 0.48 \\
& 24 April 2014 & 0.21 & 0.10 & -0.11 & 0.50 \\
& 17 October 2014 & 0.22 & 0.10 & -0.08 & 0.53 \\
& 02 November 2014 & 0.20 & 0.10 & -0.13 & 0.47 \\
\cline { 2 - 6 } NDBI & 23 March 2014 & -0.20 & 0.09 & -0.52 & 0.12 \\
& 24 April 2014 & -0.20 & 0.09 & -0.55 & 0.00 \\
& 17 October 2014 & -0.21 & 0.09 & -0.52 & 0.10 \\
& 02 November 2014 & -0.19 & 0.08 & -0.49 & 0.11 \\
\hline
\end{tabular}

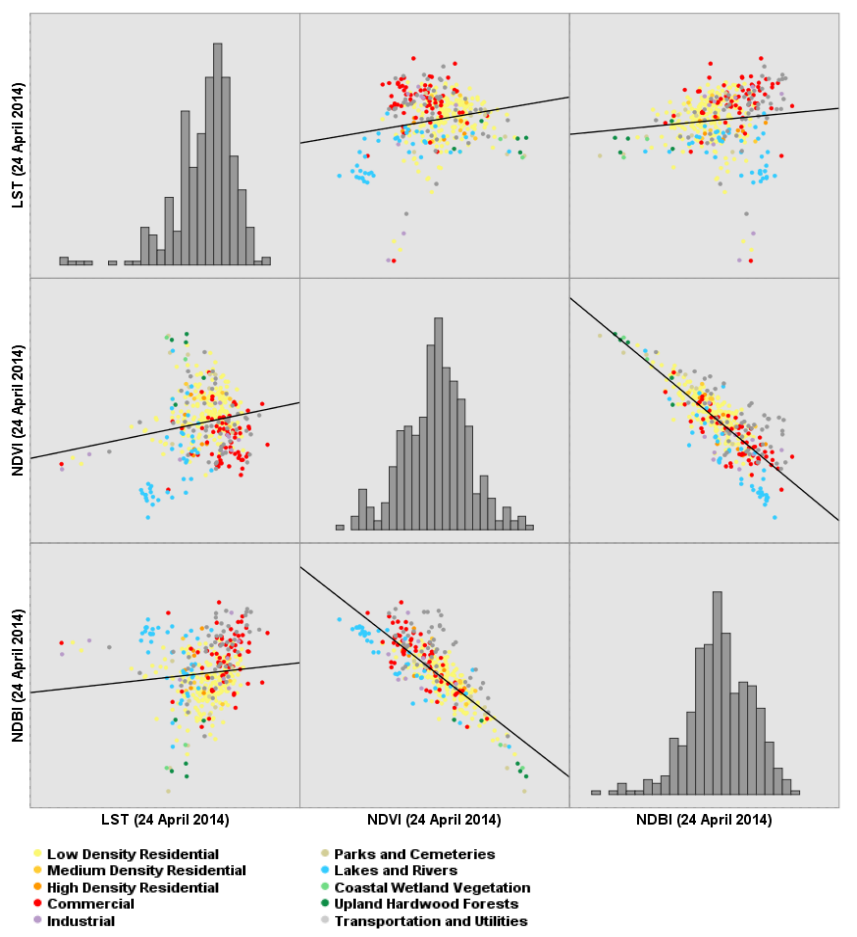

Fig -8: The statistical correlations for 24April 2014. The black solid line refers to the linear fitting curve.

\section{CONCLUSION}

In this study, we examined the potential of remotely sensed data to explore the relationship between land use/land cover and urban heat islands. More specifically, we focused on the spatial distribution of LST, NDBI, and NDVI. Land surface temperature using OLI and TIRS data with land surface emissivity derived via NDVI thresholds method was applied to four cases, namely, daytime in winter "dry season" (March $23^{\text {rd }}$, April $24^{\text {th }}$, November $2^{\text {nd }}$ ) and daytime in summer "wet season" $\left(\right.$ October $\left.17^{\text {th }}\right)$ in 2014. Surface temperature from TIRS band 10 data was retrieved using the procedure described by USGS [35].The surface temperature distribution in the city of Fort Lauderdale indicates that the highest surface temperature during study period ranges from $33^{\circ} \mathrm{C}-39^{\circ} \mathrm{C}$. The study also found that despite the observed wide ranges of LST in each land use category, the differences between these categories in terms of LST, NDVI, and NDBI are statistically significant. The most variation was observed in low density residential land use which is consistent with various extents and maturity of the vegetated land cover.Given that the most devastating effects of heat waves are associated with populations with a lower socio-economic status, an important future line of research would be to examine the relationship between LST, NDVI and NDBI and morbidity and mortality associated with heat waves. Another potentially fertileground for future investigations will be focused on plant communities that have the strongest impact in mitigating the urban heat island phenomenon.

\section{REFERENCES}

[1]. Intergovernmental Panel on Climate Change (IPCC). Fourth Assessment Report (AR4), Working Group 1: The Physical Science Basis, Chapter 3.2.2.2. Urban heat islands and land use effects.2007. URL:https:Iwww.ipcc.ch/publications_and_data/ar4/wg1/en /ch3s3-2-2-2.html(accessed 03/26/16).

[2]. United States Environmental Protection Agency (US EPA). Urban Heat Island basics. In Reducing Urban Heat Islands: Compendium of Strategies; Chapter 1; Draft Report; US EPA: Washington, DC, USA. 2008.

[3]. Hamdi, R. Estimating Urban Heat Island Effects on the Temperature Series of Uccle (Brussels, Belgium) Using Remote Sensing Data and a Land Surface Scheme. Remote Sens. 2010. 2773-2784. http://dx.doi.org/10.3390/rs2122773 [4]. American Planning Association (APA). Land Based Classification Standards. 2001. URL: https://www.planning.org/lbcs/standards.

[5]. Taha, H.; Hammer, H.; Akbari, H. Meteorological and Air Quality Impacts Of Increased Urban Surface Albedo and Vegetative Cover in the Greater Toronto Area, Canada; LBNL-49210; Lawrence Berkeley National Laboratory: Berkeley, CA, USA, 2002.http://dx.doi.org/10.2172/799565 [6]. Svensson, M.: Sky View Factor Analysis-Implications for Urban Air Temperature Differences. Meteorol. Appl. 2004. 11 , 201-

211.http://dx.doi.org/10.1017/S1350482704001288

[7]. Unger, J.: Connection between Urban Heat Island and Sky View Factor Approximated by a Software Tool on a 3D 
Urban Database. Int. J. Environ. Pollut. 2009. 36, 5980.http://dx.doi.org/10.1504/IJEP.2009.021817

[8]. Voogt, J., Oke, T.: Thermal Remote Sensing of Urban Climates. Remote Sens. Environ. 2003. 86, 370384http://dx.doi.org/10.1016/S0034-4257(03)00079-8

[9]. Li, Z-L, Tang, B-H, Wu, H., Ren, H., Yan, G., Wan, Z., Trigo, I.F., Sobrino, J.A. Satellite-derived land surface temperature: Current status and perspectives, Remote Sensing of the Environment.2013. 131, 1437.http://dx.doi.org/10.1016/j.rse.2012.12.008

[10]. Smoyer-Tomic, K., Kuhn, R., Hudson, A.: Heat Wave Hazards: An Overview of Heat Wave Impacts in Canada. Natural Hazards.2003. 28, 463485http://dx.doi.org/10.1023/A:1022946528157

[11]. Rinner, C.,Patychuk, D.,Bassil, K., Nasr, S., Gower, S., Campbell, M.: The Role of Maps in NeighbourhoodLevel Heat Vulnerability Assessment for the City of Toronto. Cartogr. Geogr. Inform. Sci. 2010. 37, 3144.http://dx.doi.org/10.1559/152304010790588089

[12]. Whitman, S., Good, G., Donoghue, E.,Benbow, N., Shou, W.,Mou, S.: Mortality in Chicago Attributed to the July 1995 Heave Wave. Amer. J. Public Health.1997. 87, 1515-1518.http://dx.doi.org/10.2105/AJPH.87.9.1515

[13]. Robine, J., Cheung, S., Le Roy, S., Oyen, H., Griffith, C., Michel, J., Herrmann, F.R. Death Toll Exceeded 70,000 in Europe during the Summer of 2003. ComptesRendusBiologies. 2008. 331, 171178.http://dx.doi.org/10.1016/j.crvi.2007.12.001

[14]. Stone, B., Hess, J.,Frumkin, H.: Urban Form and Extreme Heat Events: Are Sprawling Cities more Vulnerable to Climate Change than Compact Cities? Environ. Health Perspect. 2010. 118, 14251428http://dx.doi.org/10.1289/ehp.0901879

[15]. Akbari, H.: Potentials of Urban Heat Island Mitigation. In Proceedings of the International Conference on Passive and Low Energy Cooling for the Built Environment, Santorini, Greece. 2005. 19-21.

[16]. Taha, H.: Urban Climates and Heat Islands: Albedo, Evapotranspiration, and Anthropogenic Heat. Energy Build. 1997, 25, 99-103.http://dx.doi.org/10.1016/S03787788(96)00999-1

[17]. United States Environmental Protection Agency. EPA Home, Climate Change, Basic Information; US EPA, 2010.

[18]. Chow V., Maidment D., and Mays L.: Applied Hydrology, McGraw-Hill Publishing Company. 1988. p. 84, 91-93.

[19]. Maloley, M.: Thermal Remote Sensing of Urban Heat Island Effects: Greater Toronto Area; Report; Enhancing Resilience to Climate Change Program, Natural Resources Canada: Ottawa, ON, Canada, 2009.

[20]. Yang, L., Huang, C., Homer, C., Wylie, B.,Coan, M.: An Approach for Mapping Large-Area Impervious Surfaces: Synergistic Use of Landsat 7 ETM+ and High Spatial Resolution Imagery. Can. J. Remote Sens. 2003. 29, 230240.http://dx.doi.org/10.5589/m02-098

[21]. Linh, N. Chuong, H.: Assessing the Impact of Urbanization on Urban Climate by Remote Sensing Perspective: A Case Study in Danang City, Vietnam. International Archives of Photogrammerty, Remote Sensing and Spatial Information Sciences. 2015. Vol. XL-7/W3.
[22]. Debbage, N. Shepherd, J.: The urban heat island effect and city contiguity. Computers, Environment and Urban Systems. 2015. Vol 54. pp. 181194.http://dx.doi.org/10.1016/j.compenvurbsys.2015.08.002 [23]. Kumar, D.: Remote Sensing based Vegetation Indices Analysis to Improve Water Resources Management in Urban Environment. Aquatic Procedia. 2015. Vol 4. pp. 1374-1380.http://dx.doi.org/10.1016/j.aqpro.2015.02.178

[24]. Jusuf, K., Wong, H., Hagen, E., Anggoro, R., Hong, Y.: The Influence of Land Use on the Urban Heat Island in Singapore. Habitat Int. 2007. 31, 232-242.

[25]. Oke, T.R. Boundary Layer Climates; Routledge: London, UK, 1987.

[26]. Bottyan, Z.,Kircsi, A.,Szegedi, S., Unger, J.: The Relationship between Built-Up Areas and the Spatial Development of the Mean and Maximum Urban Heat Island in Debrecen, Hungry. Int. J. Climatol. 2005. 25, 405418.http://dx.doi.org/10.1002/joc. 1138

[27]. Xiao, R., Ouyang, Z, Zheng, H., Li, W.-F. Schienke, E.W.; Wang, X.-K. Spatial Patterns of Impervious Surfaces and Their Impact on Land Surface Temperature in Beijing, China. J. Environ. Sci. 2007. 19, 250-256. http://dx.doi.org/10.1016/S1001-0742(07)60041-2

[28]. Stone, B.; Norman, J.M. Land Use Planning and Surface Heat Island Formation: A Parcel-Based Radiation Flux Approach. Atmos. Environ. 2006. 40, 35613573.http://dx.doi.org/10.1016/j.atmosenv.2006.01.015

[29]. Zhang, X.; Zhong, T.; Feng, X.; Wang, K. Estimation of the Relationship between Vegetation Patches and Urban Land Surface Temperature with Remote Sensing. Int. J. Remote Sens.2009. 30, 21052118.http://dx.doi.org/10.1080/01431160802549252

[30]. Vlassova, L. Perez-Cabello, F. Nieto, H. Martin, P. Riano. D. de la Riva, J. Assessment of Methods for Land Surface Temperature Retrieval from Landsat-5 TM Images Applicable to Multiscale Tree-Grass Ecosystem Modeling. Remote Sens. 2014.Vol. 6. pp. 4345-4368. http://dx.doi.org/10.3390/rs6054345

[31]. Kim, H. Kim, B. You, K. A Statistic Correlation Analysis Algorithm between Land Surface Temperature and Vegetation Index. International Journal of Information Processing Systems. 2005.Vol. 1. No. 1.

[32]. Fort Lauderdale, Florida, n.d., Wikimedia Foundation Inc. Encyclopedia on-line. URL: https://en.wikipedia.org/wiki/Fort_Lauderdale,_Florida (accessed 11/24/2015).

[33]. Kim. J., Guldmann J.: Land-use planning and the urban heat island. Environment and Planning B: Planning and Design. 2014, 41, 1077 - 1099. http://dx.doi.org/10.1068/b130091p

[34]. Kumar, K. Bhaskar, P. Padmakumari, K.: Estimation of Land Surface Temperature to Study Urban Heat Island Effect Using Landsat ETM+ Image. International Journal of Engineering Science and Technology. 2012. Vol. 4. No.02. [35]. United States Geological Survey (USGS). Landsat 8 (L8) Data Users Handbook, LSDS-1574.2015. Version 1.0, URL: http://landsat.usgs.gov/Landsat8_Using_Product.php (accessed 10/15/2015).

[36]. Weng, Q., Lu, D., Schubring, J.: Estimation of land surface temperature-vegetation abundance relationship for 
urban heat islands.Remote Sensing of Environment. 2004. 89

467-483http://dx.doi.org/10.1016/j.rse.2003.11.005

[37]. Snyder, W., Z. Wan, Y. Zhang, and Y.-Z. Feng.: Classification-based emissivity for the EOS/MODIS land surface temperature algorithm," Int. J. Remote Sens.1998.http://dx.doi.org/10.1080/014311698214497

[38]. Yin, H. Udelhoven, T. Fenshot, R. Pflugmacher, D. Hostert, P. How normalized Difference Vegetation Index (NDVI) Trends from Advanced Very High Resolution Radiometer (AVHRR) and SystemeProbatoired'Observation de la Terre Vegetation (SPOT VGT) Time Series Differ in agricultural areas: An inner Mongolian case study. Remote Sens. 2012.Vol. $04 . \quad$ pp. 3364-3389. http://dx.doi.org/10.3390/rs4113364

[39] Becker, F., Li, Z.: Temperature independent spectral indices in thermal infrared bands. Remote Sensing Environment. $1990 . \quad 32 \quad 17-$ 23http://dx.doi.org/10.1016/0034-4257(90)90095-4

[40] Qin Z H, Li W, Xu B, Chen Z, Liu J.: Remote Sensing for Land and Resources. 2004. $328-42$.

[41]. Yuan F, Bauer M.: Comparison of impervious surface area and normalized difference vegetation index as indicators of surface urban heat island effects in Landsat imagery.Remote Sensing of Environment. 2007. 106 375386.http://dx.doi.org/10.1016/j.rse.2006.09.003

[42]. Qiu, W., Xu, H., and He, Z., Study on the difference of urban heat island defined by brightness temperature and land surface temperature retrieved by RS technology, Computer Modelling \& New Technologies. 2014. 18(4) 222-225.

[43]. Bhatti, S. Tripathi, N. Built-up area extraction using Landsat 8 OLI imagery. GIScience\& Remote Sensing. 2014. Vol. 51. No.

http://dx.doi.org/10.1080/15481603.2014.939539

[44]. Miscellaneous Indices Background. Normalized Difference Built-Up Index (NDBI). Harris Geospatial Solutions. URL: http://www.harrisgeospatial.com/docs/BackgroundOtherIndi ces.html(accessed 01/27/2016).

[45]. Y. Zha, J. Gao, S. Ni.:Use of normalized difference built-up index in automatically mapping urban areas from TM imagery, International Journal of Remote Sensing. 2003. 24:3, $583-$ 594http://dx.doi.org/10.1080/01431160304987

[46]. Y. Limin, X. George, "Urban Land-Cover Change Detection through Sub-Pixel Imperviousness Mapping Using Remotely Sensed Data", Photogrammetric Engineering \& Remote Sensing.2003, Vol.69, No. 9, pp. 1003-1010.http://dx.doi.org/10.14358/PERS.69.9.1003 